\title{
Living Together in the Mediatized City: The Figurations of Young People's Urban Communities
}

Andreas Hepp, Piet Simon and Monika Sowinska

\subsection{INTRODUCTION}

Since 2000, research on media and communications has devoted an increasing amount of attention to the city as an object of study. There are various reasons for this. The city has once more become a topic of great interest for the social sciences, if only because of the increasing tempo or processes of urbanization (United Nations 2015). Here the most important reference points are probably gentrification and segregation (Smith and Williams 2010). Another issue is that of changes to the city resulting from the diffusion of information and communication technologies (Castells 2000: 407-459). Research into communications and media

A. Hepp $(\square)$ · P. Simon · M. Sowinska

ZeMKI, Centre for Media, Communication and Information

Research, University of Bremen, Bremen, Germany

e-mail: ahepp@uni-bremen.de

P. Simon

e-mail: piet.simon@uni-bremen.de

M. Sowinska

e-mail: sowinska@uni-bremen.de

(C) The Author(s) 2018

A. Hepp et al. (eds.), Communicative Figurations,

Transforming Communications - Studies in Cross-Media Research, https://doi.org/10.1007/978-3-319-65584-0_3 
has a place within this more general social scientific discussion. Specific research questions have been developed that result in a focus upon the deep mediatization of the city. Topics range from the visions and limits of a 'smart city' (Townsend 2013), to the study of 'locative media' (Evans 2015 ) and '(hyper)local journalism' (Nielsen 2015), and to the way that media support urban communal living (Georgiou 2013).

This chapter deals with this last thread. We wish to examine the following question: what does deep mediatization mean to young people in their daily urban sense of community? Here 'urban sense of community' is not treated as a given, but rather as an open process that can assume different empirical forms. For instance, we might think of different forms in the city for which the 'urban' environment is the general context. But it can also involve definite urban forms of community experience, an 'urban community' in a more restricted sense of the term. Hence, we shall deal with a spectrum of community in the urban context: the increasing and many-layered dispersion of media within the city has no direct and automatic consequences for the sense of community created by and among young people. Instead, we are faced with the multi-dimensionality of different possible processes, and the way in which they change as media are transformed.

How this multi-dimensionality can be grasped without relapsing into mere description where 'anything goes' is the empirical challenge here. We wish to make clear in this chapter that research based upon a figurational perspective holds great promise for a multi-dimensional analysis of this kind. That is not just because the idea of figuration was first deliberately employed to analyze conflicts arising in one particular urban area (Elias and Scotson 1994 [1965]). It is more that developing figurational analysis within a media and communications framework allows us to grasp the mediatization of different processes of community in the urban space, without at the same time losing sight of their contradictory nature. Here we are not concerned, as Elias and Scotson were, with conflict, but rather with the process of creating and experiencing community.

In the following, we do this by studying young people in Leipzig and Bremen, two German cities each with around 550,000 inhabitants. First of all we will relate our own work to existing research on media, community and the city. Then we will detail our empirical procedure. Using empirical data, we will demonstrate the degree to which for young urban dwellers - besides family, acquaintances and colleagues - it is their network of friends that remains the primary figuration of their experience of community construction. And this has become to a very great degree a mediatized 
phenomenon. Developing from this analysis, we then turn to what we might call the figurative quality of individual sites of community construction. We are interested in the way that the mediatization of particular locations in the city lends them a particular quality of community construction, and that we can detect segregation processes linked to particular locations. This leads us to the question of the extent to which the city can be, for young people, something like an imagined community.

A study of the type we present here has its limitations. There are at least two obvious ones. First of all, our data relates to two specific cities in Germany, and we do not know how applicable our findings are for others. Secondly, we focus upon young people between the ages of 16 and 30, and we do not know whether our results would apply to people from different age groups. While we acknowledge these limitations, we presume, as did Norbert Elias and John Lloyd Scotson, that the basic features we identify here are to be found in other cities, too, and that they are also characteristic of other age groups. We consider this to be our general contribution to communications and media research into the nature of media in the city.

\subsection{Media, the City and Community}

Studying the relationship between media, city and community takes us back to the beginnings of work on media and communications. Robert Park's classic paper of 1915/1925 still repays reading for many reasons. Park emphasized that on the one hand, the decay of cities led to a 'mosaic of little worlds' (1967: 40) which, drawing an explicit parallel with Georg Simmel (2006 [1903]), promoted the 'mobilization of the individual' (1967: 40). On the other hand, he saw a clearly defined role for public communication, on the basis of which public opinion in the city developed (1967: 38). This was, he thought, a 'source of social control' (1967: 38) that transcended the various 'little worlds'. Hence, he emphasized, it made no sense to think of the city as a single community. Rather, he considered the 'urban environment' (1967: 1) as a more specific context in which different processes of communitization took place that were in part contradictory, and thus also in part the source of conflict. He treated the media above all as a means of mass communication that aided the creation of 'public opinion' and the corresponding 'control' in a thoroughly segregated city.

Park's reflections were first published over 100 years ago. They can therefore help us identify what has changed in the city and what has not. 
From today's perspective, we can still agree with Park that we should treat the city more as a specific context for different processes of communitization than necessarily a coherent community; although constructions of the city as a community are of course quite possible. But all the same, they should be treated more at the level of public communication, where their function can range from appeal to 'social control'.

By contrast, what we understand by 'the media' has fundamentally changed in 100 years. Today's urban media environment no longer consists of a few printed media for public communication, plus the letter and the telephone. With the deep mediatization of the city, this environment has become more varied, complex and also contradictory. But this, in turn, takes us back to Park's starting point concerning the role of media in the 'mosaic of little worlds'.

Recent study of the role of media in urban life is likewise concerned with this role. There is particular interest in the analysis of the city as a diverse and transcultural living space that is also in many respects segregated and gentrified. In this context, Myria Georgiou talked of the 'mediated city' (2013: 41). This concept draws attention to the fact that our experience of the city today can no longer be treated as separate from the media of communication. She is likewise interested in seeing the relationship of media and city 'from street level' (2013: 3; see also Lane 2016); substantively, this means in terms of people's 'consumption, identity, community, action'. Shopping malls are in particular locations of urban consumption, locations that are comprehensively saturated medially, while also being an expression of gentrification (cf. Bolin 2004). It can be observed that the medial construction of identity in the city takes place in a relation of tension between very different cultural definitions (Christensen and Jansson 2015: 130-152), given that the city is itself a transcultural space in which people of many different backgrounds live together (cf. Hepp 2015: 120-123). With respect to the formation of community, it follows from this that the city cannot be simply seen as a single community. Instead, we have a variety of diverse and local communities that are in part opposed to each other, as well as diasporas with a very weak sense of community (Georgiou 2013: 92-116). Here, then, media open opportunities for political action in the city, examples being 'urban gardening' or 'reclaim the streets', the organization of both of which is supported via digital media (Bridge 2009; Rauterberg 2013: 97-128). From this perspective, it is also necessary to describe this complexity of the city critically, as a medially saturated space 
of transcultural human existence. We can also include in this tradition those critical studies that have highlighted the increasing fragmentation of urban public life (Hasebrink and Schmidt 2013; Metag and Donk 2013). From this, we can see a close connection between research into media and communication and more general social science research on urbanism (see, for example, Christmann 2013; Metag and Donk 2013; Zukin et al. 2016) It thus becomes evident that we require multi-layered conceptions if we are to grasp the relationship between media, city and community construction. What would a multi-layered conception look like?

In an analysis of the link between media and the city, we continually encounter two approaches: the concept of network and that of assemblage. Accordingly, different urban social networks are studied, or networks between cities (see among others Neal 2013); or the various assemblages of people in the city are examined (see among others Farías 2010). As we have argued elsewhere (Couldry and Hepp 2017: 60-63), both conceptions do have their strengths, but they are not suited to the contradictoriness of the everyday production of meaning, of grasping existing social differentiation and hierarchization.

Hence, we think that approaching the experience of constructing urban community in the mediatized city from the perspective of figurational analysis is worthwhile, and fits in with the other contributions in this volume. This approach allows us to make use of a differentiated, multi-layered analysis that takes account of actor networks and the materiality of media, while also making possible a connection with a critical, social scientific appraisal of urbanism as initiated by the Chicago School.

If we consider the forms of community construction in the mediatized cities of today, we note that they are mediatized processes, since this is comprehensively interwoven with the appropriation of media as content and as technology. Media are important resources as contents with which community can be constructed. This is, for example, the case where public viewing contents are available that promote a common identification (Krajina 2014), or if in the communicative construction of community reference is made to particular media contents (Keppler 2014). If communities are maintained through the continual use of mobile phones, digital platforms and other media technologies by community members confirming their close connectedness through their continued communication, media are basic to the formation of community as technologies (Baym 2015: 80-111). 
With regard to urban community construction, we think it is necessary to distinguish at least three contexts. First of all, we are dealing with particular figurations of communities in the city; that is, particular groups of people who see themselves as forming a community. We can identify in these communities a characteristic constellation of actors who share a specific frame of relevance and (communicative) practices.

If these urban communities are considered more closely, one encounters a second phenomenon, something we can describe as the figurative quality of individual mediatized communitized locations. These (mediatized) locations in the city-shopping malls, meeting rooms, cinemas and so on-have characteristics that lend them a special potential for individual figurations of community. This does not mean that these qualities are inherent to these particular locations. Rather, these qualities are generated through human practice, but rendered lasting by virtue of the locational materialization. This close coupling of such figurative qualities with the character of these locations seems quite remarkable to us.

Third, the city itself can be a reference point for the construction of an imagined community, in the sense proposed by Benedict Anderson (1983). This does not mean that the city as an imagined figuration of a community is a homogeneous construction. But it is a shared connection to the construction of community-even if to different degrees for different people.

On the basis of this distinction, we intend to develop below the argument that these three levels provide an appropriate point of departure to understand the complexity of the process of community construction of young people in the mediatized city.

\subsection{The Methodical Approach}

The data we use in our analysis come from two sources. The first of these is an investigation funded by the German Research Council into the communicative networking and mediatized community construction of people from different media generations. The second source is linked to a research seminar that conducted a study specifically upon the various urban locations of community construction shared by young people.

Our study of communicative networking and mediatized community construction is based upon a contextualized communication network analysis (see Hepp et al. 2016). ${ }^{1}$ The selection of interview subjects was made according to 'theoretical sampling' (Strauss and Corbin 1996: 148-65; 
Glaser and Strauss 1998: 53-83; Strübing 2008: 29-32). The material analyzed below was collected between November 2010 and September 2011 , and includes a total of 60 cases of youths and young adults aged between 16 and 30. The data was collected in Bremen and Leipzig and the surrounding areas. The evaluation of the data was done through qualitative coding aimed at developing empirically founded theory. In coding the material, we focused upon patterns of community formation as well as structures, processes and imputations of meaning to communicative networking, and the associated underlying practices of media appropriation.

While conducting this evaluation, we encountered the phenomenon of individual mediatized community construction locations. These involved locations that had a special sense of community for young people. Between April 2014 and January 2015, we made a special study of these locations in the context of a research seminar. ${ }^{2}$ This was done in two stages: first of all, we issued an appeal to young people in Bremen to identify what they considered to be their 'most important' locations for community construction. We explicitly asked them to name places where 'stuff was going on'. These appeals were made in different ways through local media in newspapers, radio, the web-and there were a number of responses. The locations that were identified in this way were then marked on a map of the city. Following this, we studied these locations in greater detail. Observations were made and interviews conducted, following which the material was coded according to Grounded Theory.

This material enabled us to arrive at an understanding of the urban community construction of young people at the three levels outlined above: the figuration of communities in which they live; the mediatized community construction locations and their figurative qualities; and the construction of the city as an imagined community.

\subsection{Young People's Friendship Groups in the City}

Our study of communicative networking and mediatized community makes clear the varied levels of communal life that are important to young people: they do not feel that they belong simply to one community, but to various communities - even if some are more important than others, according to local distribution, thematic orientation and plurality. ${ }^{3}$ What is striking is the high value placed on the local in community processes: even if young people are strongly oriented to particular 
themes in their community construction (popular culture, a religion), or are instead very plural and so among themselves globally oriented, it is local communities that are important to them. To different degrees this is true for families, members of a school or college class, work colleagues, the community of individual associations and experiences with various acquaintances. However, the immediate group of friends has for young people a special importance, their 'clique' as they often call it. We therefore want to direct our attention to this phenomenon below. We focus upon young people who live in Bremen or Leipzig and the surrounding areas, and who in their experience of community are strongly oriented to these cities.

There are three striking aspects of these friendship groups that emerge from a consideration of their communicative figuration. First of all, the city is an important context for their circle of friends when they want to do something together. Second, this group of friends is the stable framework for community construction. Third, these figurations are supported by a media ensemble that carries with it both a potential for the communicative practices of members of this circle of friends, as well as certain restrictions.

If one considers the actor constellations of this circle of friends, it becomes evident that the core of the circle is formed by friends who 'all come from around here' (Mala Hempel, 21, Bremen area, trainee nurse); and 'with whom one stays in touch regularly' (Konstanze Mitscherlich, 26, Leipzig, printer). ${ }^{4}$ This shared space of the local is important for the way in which the friendship circle is experienced, as Mala makes clear when she distinguishes between close and less close relationships. This shared local space allows them above all direct communication:

... so, I am fairly thick with her ((laughs)) [...] we don't really speak on the phone, if we do then I write more on Studi [StudiVZ, an online platform]; or maybe text, something like that. So it is with her that I am mostly in contact. And then with other girls, that's OK. So of course, we write now and then, when something comes up. But now I don't think we would phone on my account. (Mareike Bonitz, Leipzig, 19 years old, student)

The circles of friends that we interviewed ranged from two to ten persons. Konstanze said, for instance, that she divided her circle of friends into 'rings', with an 'inner ring' of eight persons which was 'the 
important' group for her. In this way, she emphasized that the links of persons to each other were not necessarily equal-her friends 'just came together $[\ldots]$ that does not mean that the people who I now see as the most important, that they are connected with each other in exactly the same way'. Konstanze sees herself at the centre of a circle of friends and emphasizes that the relationships between these friends themselves vary.

Lara-Marie Michaelis (28, Leipzig, cook) describes her own circle of close friends similarly. This is made up of 'six or seven girls $[\ldots]$ maybe also three other boys'. They tend to meet up separately, 'because working hours always makes things a bit complicated'. To have a solid core to a circle of friends is linked in this case to changing constellations for individual meetings. The friendship groups for those we interviewed tend to fluctuate over time. Mareike, the Leipzig student, exemplifies this:

Thus, something like a solid clique developed. Over the years, though, more and more drifted off because they moved away or school, work, whatever. So it somehow became a bit fractured. But the core is still there.

Those we interviewed felt it very important to do different things together with their close friends, not least spontaneous meetings: 'Oh what to do this evening, let's open a bottle of Sekt or something, have a nice evening' (Katja Hosner, 21, trainee therapist). Or the way that Henning Rowohlt (16, Bremen, school student) described this kind of spontaneous meetup: 'In the summer we are really always outside, on the Weser [the river] [...], behind the stadium, playing music, drinking some beer.'

Besides these spontaneous events that are arranged quite casually, there are meetings that are organized more in advance. Here, media facilitating mutual communication plays a role. Evenings are planned with mobile calls, the web is used for information and agreement reached in various ways before meeting. In part, this takes place during evenings out. Henning reports, for instance, that his friends often check on different events through the internet 'and then sitting [in the pub], Saturday evening, having a drink, my mates get in touch: hey, want to go there?'.

Arrangements like this do not only occur using mobiles and when going out together. Digital platforms in particular, such as Facebook, are used for the planning. For example, Felicitas Franke (Leipzig, 17, school student) emphasizes that from her point of view Facebook is much 
better than email for friends to draw each other's attention to events and to arrange to meet: 'so there is always an event and then you know who is going, and then you can go too'. Emails are not practical, since 'a lot of people don't check their mails' (Felicitas). Other interviewees also stress that they use Facebook within their group of friends to find out 'what's going on, what's happening at the weekend, what happened on the weekend $[\ldots]$ and otherwise finding out what's going on' (Mala Hempel, 21, Bremen region, trainee nurse). A digital platform offers young people the possibility to arrange to meet up with friends, draw attention to events or just stay in touch.

In each of the groups of friends formed among those we interviewed there is a particular set of established media that supports communication within the group and for other purposes. This set of media contributes to the maintenance of the groups. By using the same media-mobiles, media content, especially digital platforms-each person is bound into a constant stream of group communication. There is some pressure here to use the right media, so that an individual does not get shut out of communication. This is especially clear with digital platforms, Facebook above all else. For several groups this has become the 'central' (Henning) medium for contact and meeting up. This is felt particularly by those who had not so far joined up. They have to find other ways so that they do not get shut out of group communication. Konstanze describes her experience with this as follows:

So there are times when it's like 'So you, Wednesday, are you coming?' If I then say 'Wednesday?' - 'well I did post about that'-If I say: 'Yes, sorry, don't have it, can't check!'-And then I get a sort of special catchup, what is going on Wednesday and then it's fine.

Nor is Lara-Marie on Facebook, saying that she is 'constantly asked why she isn't on Facebook', that she can't be Googled as a result, and whether 'she can't register'. She responds to this as follows: 'Somehow I don't really listen. Then I decided to definitely do it the day after tomorrow, and then, yes, that is I think really no problem.' So LaraMarie makes up her mind to give into the pressure and register with Facebook-as many other interviewees report. Mala said in her interview with us that she was only pushed by her friends to join Facebook, 'because they all had it'. And she went on: 'I wasn't on there until a few months ago. But then everybody had Facebook; and then [I] had it as 
well.' She, too, had to adopt the relevant communication form to prevent being closed out of the circle of friends. Even if the telephone, texting and emails are part of the media set used by the group, they are not really any substitute for digital platforms, since 'why write an email if you can write a lot quicker on Facebook?' (Felicitas).

The pressure articulated here can also be related to produced media contents. Felicitas describes this as follows: 'you mostly [listen to] what friends listen to, and then it is on Facebook, they write the words of the song-oh yes, I love the song! - then you listen to it too and like it too'. Jana Jäger (28, Leipzig, Primary School teacher) describes a similar process, and says that ' $\ldots$ if you spend more time with friends $[\ldots]$ you come across new CDs'. This 'social dependence', as Jana calls it, forms the expectations articulated in group communication within the figuration of the group of friends.

The above illustrates the high value placed on friendship groups in the community life of young people. It is evident that the set of media used both stabilizes its figuration, while also creating a degree of pressure on its members.

How does the urban context fit in here for the circle of friends? This question can best be answered if the city is seen as a space of opportunity for young people. The following more detailed extract from an interview exemplifies that. Katja Hosner describes an evening spent together with friends:

Well, first we were in the restaurant, and then we thought, now we can really do something, everyone is in such a good mood. So we went straight to the cocktail bar for their happy hour, and the happy hour was over and then we went to the next cocktail bar's happy hour. And the evening just didn't want to end (smirks). And then we just decided then to go to someone's place, we got on the tram and went to her place, we stopped off here quickly because I've got a hookah. We picked it up and left for her place down the street (smirks). Why didn't we do it here? Well (smirks), and then it went on to two and then I had to get up at six to go to school.

Besides the many things that can be done in a city, the quote emphasizes a second aspect: the locations that are important for sharing such fun with friends are concentrated in the city. Lara-Marie emphasizes this, too; for her, Leipzig is 'the city of short cuts': 'You can really, if all else fails, just walk from A to B. I think that is fantastic. It is sometimes like a village, you always meet someone.' 
Lennard Schimmang (18, Leipzig, community service worker) also stresses the way locations to which you go out are concentrated in the city, contrasting this with his home village, where 'nothing ever happens'. In the city you 'just have more possibilities'. There is a 'big cinema and a few nice pubs'. Susanne Mattuschek (23, Leipzig, court clerk) describes the city as a context where 'there is simply more to do', and where you 'have all kinds of possibilities'. She also compares Leipzig, where she now lives, with the small town where she came from, and where 'basically nothing ever happens'. Tim Lautermann (21, Leipzig, student), who also moved to Leipzig from a small town, quickly realized that the city offered a whole range of opportunities to be taken on the spur of the moment, and described it as a 'certain kind of freedom'. For him, this 'freedom' was to do with the spontaneity opened up by the urban context.

The possibilities that the city offers can be used without needing to put much effort into travelling. Lara-Marie stresses that 'here in a big city I don't really need to have a car $[\ldots]$ and so want to live as close as I can to everything and not somewhere where I have to travel for half an hour to my friends'. Jasmin Preußler (25, Bremen, trainee teacher) says much the same thing: 'It is just so important to me that I live in a city where I can get everywhere, where I get to the centre quickly.' The city is a space of opportunity that opens up a wide range of possibilities to a group of friends, and so also the chance of doing things on the spur of the moment. All the same, it is the figuration of the group of friends that is relevant to the way in which the young people we interviewed form communal bonds.

The group of friends has assumed such an importance that some activities are felt to be less attractive if done without friends. Felicitas describes, for example, that she does not go to parties if her 'friends are not going where no-one knows anybody'. It is the 'sense of being together' (Konstanze) itself that is central, not the particular event or activity. The possibilities that are exploited in the city are heavily influenced by the interests of the group as a whole. For instance, Lara-Marie emphasizes that 'my friends like this music [drum'n bass], [...] I can really get into the music for a whole evening, I do that.' Katja describes something similar: she 'looks at new things that would not to begin with have interested me so much, but then I say: perhaps that would be great if I went with two or three people'.

We can summarize what we have established so far on the basis of our interview material. It is plain how important groups of friends are for the 
young people we interviewed. Besides family, it is the central figuration of community. We can see a certain pattern here, quite independent of educational background or the social position of those we interviewed. In the forefront is having fun with others, taking the form of diverse practices through which the community of the group of friends is created. The set of media employed plays an important strengthening role here for the group of friends. Members of the group feel a certain pressure to use the media that dominate in the group-both as technologies of joint communication and as substantive resources for mutual communication. In this way, the existence of a 'networked collectivism' (Baym 2015: 101) can be seen to typify the group of friends, rather than a 'networked individualism' (Rainie and Wellman 2012: 115). There is intensive communicative networking especially in local groups of friends, in which the shared experience of common things and events is very important. The city is consequently a special space of opportunity.

\subsection{The Figurative Quality of Mediatized Locations}

Our presentation of the friendship group as the central communicative figuration for the urban community construction of young people shows how important individual locations in the city are for this: places to which one goes on a night out, where one meets up, does things together, or experiences things together. Seen from this perspective, a location is a place with a special meaning - not something physically given, but places whose meaning is created by people through repeated and varied interaction (Massey 1994: 39; see also Berg and Roitsch 2015 and the contributions in Christmann 2016). Put another way, localities are, materially and physically, socio-culturally defined places with shared space for human interaction (Hepp 2015: 187). By referring here to mediatized places of community construction we seek to emphasize two things. First of all, the places are not simply something that is counterposed to the use of media. Instead, today's localities are largely created through media-related practices, and are in this sense themselves mediatized. Secondly, our interest is directed to those places that for young people have a great potential for creating a sense of community. We are thinking here of semi-public places, places to which young people have general access, depending upon their financial resources.

In the light of such ideas, we published the appeal mentioned above in the Bremen local media, inquiring about those places 'where 


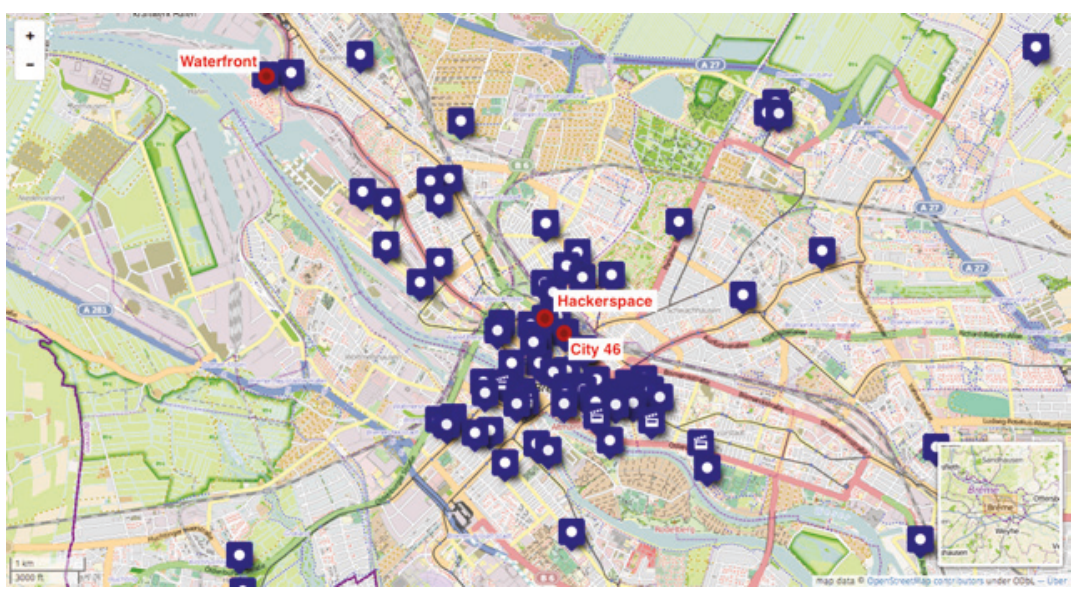

Fig. 3.1 Mediatized public places for community-building in Bremen. This figure presents a section of the map that is available online. See here http://www. hundertorte.uni-bremen.de

something was going on' and thus had this kind of enhanced potential for community-building. The responses received were marked on an Open Street Map (see Fig. 3.1), in the course of a student research seminar linked to the project.

This map certainly does not exhaust all the mediatized places of community construction in Bremen. If the map is examined more closely, it becomes clear that the places identified-from squares and open spaces, to pubs, the stadium, cinemas and other kinds of cultural sites-are localities that hold a special potential for the young people's communities. This is a bias that is given by the way the material was collected and which corresponds to the object of our research. The localities identified, as also particular kinds of localities, are concentrated in specific parts of Bremen. This partly has to do with the segregation of the city: there are well-to-do and partly gentrified areas such as Ostertor and Steintor, where many of the cultural places and also pubs are located; and in contrast, there are other parts of the city, such as Gröpelingen, which are strongly associated with migrants, and where there are only few places for community construction, such as the shopping mall Waterfront. The results of the visualization provided by the above map formed our point 
of departure in the study of individually mediatized places of community construction through ethnographic observation and interviews. We select three examples here: a shopping mall, a communal cinema and a hackerspace. The idea is to make a comparison between these places, treating them as part of a spectrum of mediatized places of community construction.

\subsubsection{Shopping Mall}

One example of a mediatized place of community construction is the shopping mall Waterfront. Opened in 2008, it was built on former dockland in the city district of Gröpelingen, once an area where dock workers lived, but whose population is now 40 per cent migrants from over 50 states, but especially Turkey and Bulgaria. In Bremen's deprivation index, Gröpelingen lies in the bottom third (Freie Hansestadt Bremen 2010: 8). Waterfront attracts young people from the neighbouring city districts, and not only for what is sold there. There are large open areas in which different groups of friends meet. They also find the free wi-fi available from the fast food outlets and cafés an additional attraction. Besides that, events are regularly held in the mall: live appearances or particular artists, fashion and car shows, song contests, children's programmes and, above all, public viewing of TV. Waterfront is therefore a commercial space that, besides being a shopping experience, also offers economically disadvantaged young people the opportunity to meet, use the internet together and have fun.

The figurative qualities of this mediatized space of community construction are exemplified by the public viewing of TV. On days when the local football club is playing, amongst others, a screen and seating are set up in the Food Court (see Fig. 3.2).

The circular space of the Food Court has a glass roof and is connected to the shopping mall by two passages (see for the following Andrae et al. 2015). Tables and seating are arranged in circles in the court, surrounded by a variety of cheap food outlets. The $25 \mathrm{~m}^{2}$ LED screen on which football games are shown is fixed to one of the walls of the Food Court. When public viewings are taking place there are around 500 people of different ages present, judging by the seating. From the interviews that we held during events, it turned out that some of those present made a regular thing of attending. Six of the eight interviewed said that 


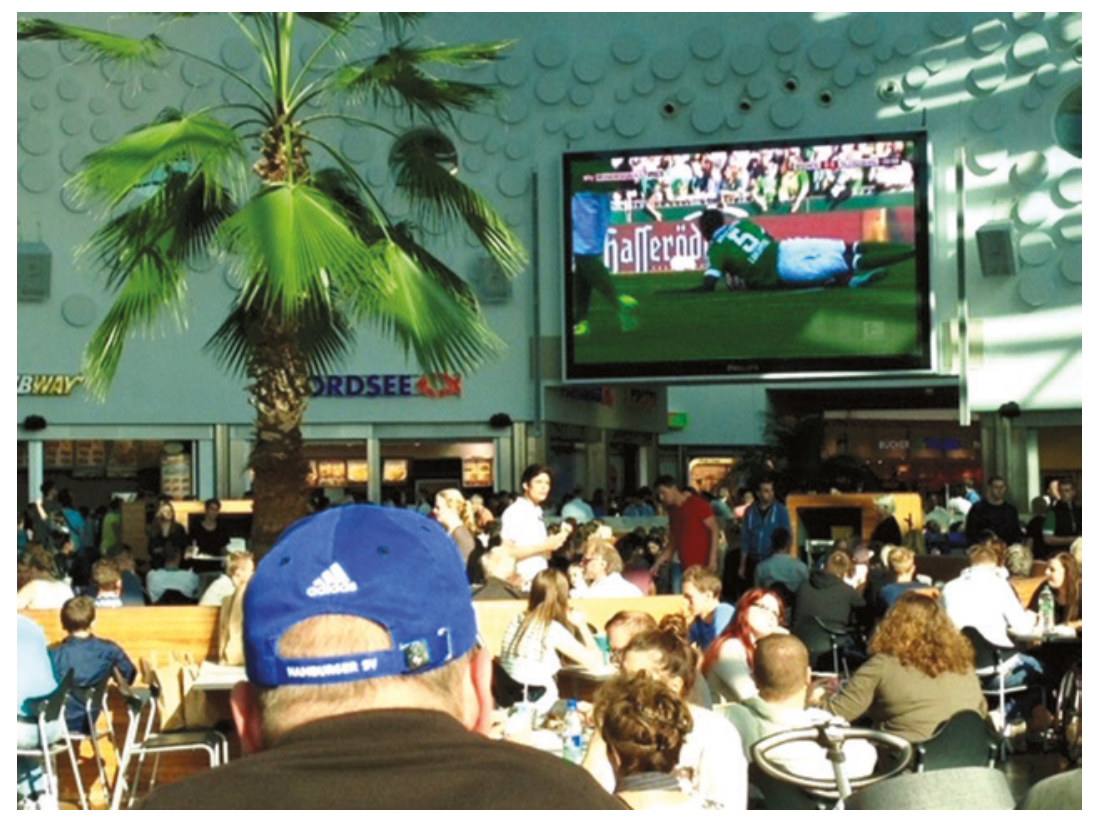

Fig. 3.2 Public viewing in the Food Court of Bremen's Waterfront Mall

they had been attending live broadcasts at the Waterfront in groups for a long time. Some thought that a live viewing was better than going to the stadium, because of the special qualities of the shopping mall:

[...] if I'm honest, here you can eat what you like and meet a lot of people and that would be a lot more difficult to do in the stadium with several people. [...] Because you can just do that here with friends. The main thing is, for me that is the thing about football: it is less about the game than, um, to watch it with friends. (Manfred, visitor to public viewing)

From this short passage, it is clear how much watching a big screen in the shopping mall has to do with the sense of being together with friends. This is confirmed by observation of such events. From the way that tables and chairs are arranged (see Fig. 3.2), it is plain that very few of those present are alone. It is much more usual to go as a couple, with friends or with family to a screening. There is seldom direct 
communication between these groups. The voice of the commentator to the live screening dominates the space, and the audience follow the game closely. If they speak at all, it is within their group or to family members. Only occasionally there is restrained cheering and clapping. In the middle of the Food Court are mostly middle-aged and older people, who concentrate on the transmission. Groups of youths are scattered around the edges; they move around from time to time, and turn now and then from the screen to their smart phones or to conversation with their friends.

The special figurative quality of this shopping mall is to provide a commercial space that, besides providing opportunities for shopping and socializing, also offers events that people on low incomes can share with their families or groups of friends. In this sense, Waterfront is a place providing a reference point for diverse figurations of people who, while not being in direct contact with each other, share experiences with friends and family.

\subsubsection{Communal Cinema}

In the middle of Bremen city centre, about a five-minute walk from the main railway station, there is the communal cinema, City 46 . This has a different figurative quality. The institution goes back over 40 years, having been founded in 1974 in connection with the student movement of the time, seeking to promote a more reflexive approach to the media. ${ }^{5}$ In 2011, the communal cinema moved from a working-class district into the city centre, and it has since then shared its space in the former commercial City Kino with an improvisational theatre company, changing its name as a consequence from Kino 46 to City 46 (see Fig. 3.3).

The former City Kino dates from the 1950s, and both interior and exterior have been deliberately preserved and not modernized. Approaching the cinema, a visitor is greeted by the suggestion of nostalgia given by a neon sign. Once inside, there is a very striking stairway with a mirrored wall that likewise dates from the 1950s. The styling of the place reflects a consciousness of tradition on the part of the governing board, marking off the communal cinema aesthetically from the city's commercial multiplexes (cf. Gerhard et al. 2015). As someone who has worked in Bremen's communal cinema for many years emphasized in interview, those running City 46 rate very highly the choice of films shown. They should involve either some element of social criticism or 


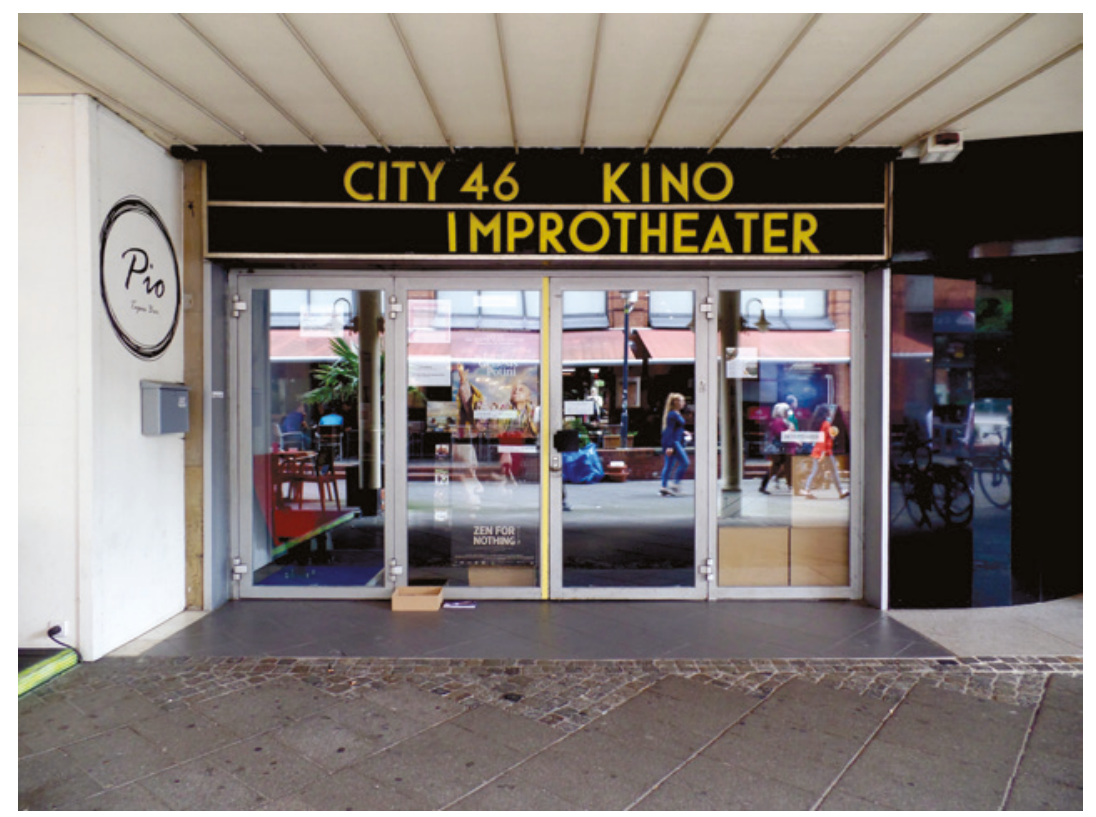

Fig. 3.3 Communal cinema City 46

have some special aesthetic value. It is a matter of the emphasis adopted, in which 'sometimes $[\ldots]$ the emphasis is more on the aesthetic, sometimes $[\ldots]$ more on the political side' (Peter Maier, employed at City 46).

If the figurative quality of City 46 is examined more closely, it becomes apparent that particular sets of films address particular groups of people-the cinema does not direct itself to individual cinema-goers. Specifically, cultural programming is practised. Peter Maier noted that 'there are not a lot of members of a proletarian milieu, if there is such a thing anyway. Our audience is bourgeois, that's clear, it is also older.' He did, however, emphasize how the composition of the audience changed from one film theme to another. The shifting emphasis of programming and the associated co-operation with various Bremen cultural and educational groups is designed to address different communities:

And that is just true of many of the things we show, they are very much to do with the film's theme, or a series of films is oriented to a target group. 
But that is a good thing, because in this way you get a natural palette, we are really I think well linked up with the migrant scene, they are always just pleased to be able to see sometimes stuff from back home. There are always films from Africa, we've got some in November, another series. Or again, this year art and film has been a big thing, the art scene is a bit stronger there than otherwise.

Maier emphasizes that those running the cinema place great store in making the cinema a 'social place' through film programming and related events, making it somewhere special. The communal experience of the cinema audience provided a sense of community of especially 'good quality'. These statements were confirmed by interviews with members of the audience: 'You share impressions, ideas, you comment' said one audience member, and another suggested that 'you have the feeling that everyone feels the same thing, because that is so great'.

Going to the cinema is seen by audience members as something related to their own lives and interests. Examples might be historical or musical interests, or belonging to a particular migrant group, and thus a consequent interest in films in one's own language. In this sense, City 46 is not a place where particular groups meet up. It is a place where shifting constellations of different groups of friends are formed according to the films being screened, all meeting as a communal cinema audience. The special figurative quality of the space is thus derived from the themes of the screenings, which address quite different groups.

\subsubsection{Hackerspace}

It is already plain from the professional presentation of the home page for Hackerspace Bremen e.V. that this is run by a group of engaged and enthusiastic 'people interested in technology, who have fun with informatics, electronics and mechanics' ${ }^{6}$ Their activities focus on the use and creation of media technologies, open source projects, internet policy and online gaming. In the hobby workshop. it is possible to use tools and equipment together with others. Among the equipment available is a $3 \mathrm{D}$ printer, a soldering station, a laser cutter, an electric drill, oscilloscope, a sewing machine, a CNC milling machine and so on.

Hackerspace has premises in the city centre, only a few minutes from the main railway station. Behind a back courtyard, you find a small building with a common room of about 35 square metres. In the middle, a number of tables have been pushed together to create a large work 


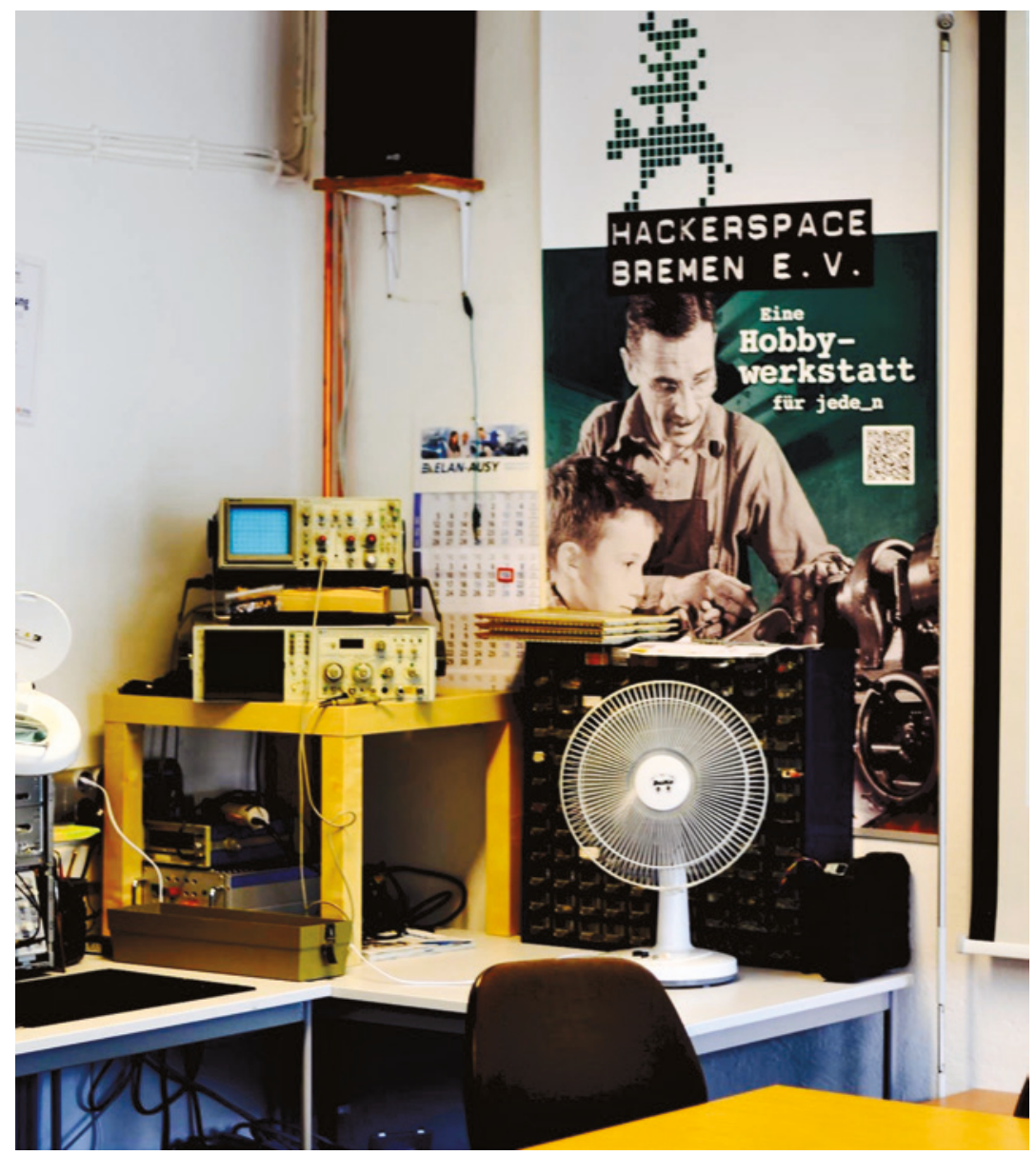

Fig. 3.4 Interior of Hackerspace

surface liberally supplied with electrical points, and here several people can work together (cf. Baumgarten et al. 2015). At the end of the work surface there is a screen and projector, and in the left-hand corner of the room there is a sofa. Along the sides of the room there are workstations and various technical apparatus, tools, cables, electronic components and other related material (see Fig. 3.4). There is also another room that is used as a store and workroom. 
While the accommodation has the atmosphere of a hobbyist's workshop, the location of Hackerspace has no special significance for its users. The chosen location is more functional than anything else: the amount of space, the central location and the possibility of using it as a workshop. From interviews and participant observation, it is evident that Hackerspace is mainly used by men between the ages of 20 and 60 who are interested in technology. They come from many occupational backgrounds, especially technical occupations. School and college students are also active in the association, the most important people here being the committee and association members who are organized into different groups by interest. Apart from external experts who sometimes come and give lectures, there are also visitors to events and workshops. However, Hackerspace remains basically a place 'where you can talk about technology and from time to time use equipment that would really be too expensive to buy yourself' (Janosch, committee member, Hackerspace Bremen e.V.). Members of the Hackerspace governing body see it as sharing in a worldwide network. As Janosch continued: 'there are different networks that you can use, different mailing lists where you can now and then ask for help if [...] if something here does not work or goes wrong $[\ldots]$. We help each other $[\ldots]$ if there are problems, or if someone wants to do something involving the whole city.'

Among the places for community construction discussed here, Hackerspace is certainly the one most strongly bound up with media technology. Besides their own special app for members and professional involvement with the press, for which all available channels of communication are used, even internal communication is media-based: internal processes are organized by a wiki. Discussion on specific technical topics is available outside the workshop space through online forums and email distribution lists. And even in 'hacking' it is a matter of practices that are in the broadest sense related to media. This includes the re-engineering of 'older' technologies ('hacking' an old sewing machine) as well as experimenting with 'new' technologies, for example, the $3 \mathrm{D}$ printer. The figurative quality of Hackerspace is therefore that of a place that is thematically focused, and through its use of technology offers 'alternative' groupings possibilities for working and socializing together. The 'alternative' nature of activities is related to the fact that media technologies are used to design and make individual products or spare parts that are different from standardized mass market goods. If in the places we have studied we might see the beginnings of a 'smart city' and of a 'code/space' 
(Kitchin and Dodge 2011) — the linking up of communication technology with the social formation of location-then it is most developed here, within an alternative framework. Hackerspace is a place that one member described as a 'home for nerds', as 'Nerdistan': 'our similar interests mean that at this level we come together after we have finished work' (Bruno, member of Hackerspace Bremen e.V.).

If we review the locations with which we have dealt-the shopping mall, the communal cinema, Hackerspace-then it becomes more clear what we mean by the figurative quality of mediatized places of community construction: whatever the place, access to it or the possibilities for interaction for groups there, these places have differing potential for community in the city. Remarkably, the commercial shopping mall seems to be much more open to friendship groups and cliques of young people from disadvantaged areas of the city than the other spaces. ${ }^{7}$ Of course, the communal cinema is in principle open to all, and sees itself as having a particular cultural mission. Its programme does, however, address very specific social and friendship groups. Hackerspace in its courtyard seems to be the most closed. Ultimately, it is for individuals and friends interested in technology who find there an alternative possibility for community construction related to technology. It is not a communal space that has any other attraction.

Further, those three localities can represent a typology of mediatized places for community construction. The shopping mall is a commercial space for situative community construction, to which we can add pubs, street festivals and concerts in public spaces. These are mostly patronized by young people with their friendship groups, the orientation to the event being a situative one. The communal cinema is a cultural and educational space, along with other cultural establishments. They address very specific and shifting groups, for whom they are a communitized space. Finally, the Hackerspace can be seen as an alternative space for community construction. We can add to this urban gardening and places for alternative culture. Common to all of these is their appeal to very clearly defined groups who see themselves as representing an 'alternative'.

From this, there emerges a dual segregation of communal life in the mediatized city. On the one hand the various spaces of community construction address very different individuals and groups of friends, according to their distinct figurative qualities. On the other hand, these spaces are very unevenly distributed around the city. Depending on how one moves as an individual or with friends through the city, and the kind of places visited for community construction, the experience of community in the city can be very different. 


\subsection{The Mediatized City as an Imagined Community}

In conclusion, we want to emphasize a third aspect of the urban communitization of young people: if one considers cities as social constructions, they can acquire the status of an imagined community (Jarren 2013: 53). If we link this argument to our data on the communicative networking and community construction of young people and their friendship groups, we find ourselves facing a paradox: not every young person for whom the city is an important space of opportunity for community thinks the city as imagined community to be very important.

At this point, it is worth coming back to the interviews that we carried out. Juliane Brandt (23, Bremen, trainee instrument maker) stated that 'Bremen is not important for me, my home is important, and my home is $[\ldots]$ where my friends $[\ldots]$ are.' The city is an important space of opportunity that she would not like to do without, but this particular city, as an imagined community, has no great importance to her.

Do statements like this just mean that, for the young people we interviewed, the city as imagined community is insignificant? That would be too easy a conclusion to draw. Tom Friedrich (26, Bremen, policeman) states quite explicitly that the city in which he lives is, besides his relationship and family, emphatically a community. So the city as an imagined community can be found in our data. And to recognize the patterns, it helps to look more closely at the way in which young people view the totality of communities in which they position themselves subjectively (Hepp 2013: 122).

As touched on above, we can identify at least four of these horizons of communitization: localists, centrists, multi-localists and pluralists (see Hepp et al. 2014a, b). To put it simply: localists are people whose communal life takes place mainly at the local level, as manifested in their primarily local communicative networks. The sense of community of centrists comes from a particular issue or concern; for example, a religion or some aspect of popular culture. This provides the dominating orientation of their communicative network and sense of community. Multi-localists favour several particular sites, which is reflected in the way that their communicative network is extensive and translocal. Pluralists, finally, are people who involve themselves in very different and in some cases casually formed communities, and are thus correspondingly extensively networked. Even if some individuals combine elements of these four types, this typology helps us understand the way in which the mediatized city as imagined community plays a role in the life of our interview subjects. It would be too simple to 
say that the imagined community of the city is only relevant to localists. In our data we can find all four types of young people for whom much the same is true as Tom Friedrich: the city as imagined community has a relevance to them. The connection is instead something rather different: if the city has a sense for these young people of being an imagined community, then for each of these four types this manifests itself in a specific manner.

We can begin with localists, something Konstanze Mitscherlich (26, Lepizig, printer) says is especially significant. Regarding her home city of Leipzig, she notes that 'friends take some part in politics, or make a fuss at city council meetings, and so a Leipziger in this way get to know about important things, sort of through verbal propaganda'. Not only does she feel she belongs to the city as an imagined community, she also keeps in touch, if indirectly, with political events and goings on in the city. She values, as do localists generally, strong local networks and being anchored in the communication space of local media. Not only does she inform herself about local political matters through newspapers, TV and the web, but also from her local friends who take part in city politics.

It is different with centrists, who approach the imagined community of the city very much on the basis of their own biography and its associated apprehension of community. One example is Dirk Herrmann (26, Leipzig, independent agent for artists), whose sense of community and also his communicative network is directed towards the music scene. Although he sees himself as a Leipziger, and his attachment to the city's imagined community is of relevance, this is overwhelmingly channelled through the Leipzig music scene. This is the dominant issue that for him opens up the city as an imagined community. As he says himself:

And this attachment to these artists, that it is the same for everyone, whether you now [have] a band in Hamburg, or in Berlin, or in Cologne, or in Mannheim, or wherever. That is something they all share [...] The music is different, [but] but everyone has the same baggage in whichever city.

The city as community therefore plays a role with centrists if their dominant interest has a connection with it. If this is so, then this will be reflected in the communicative network. For Dirk, this last element is the music scene, including related websites and magazines for which he also writes.

Our material shows that even multi-localists can feel attached to a particular city. Here we can detect clear parallels with what we have already 
established with respect to localists. What is special about multi-localists is that their imagined community of a city is experienced in connection with other places. Important here is growing up in one place and then moving away, leaving the original group of friends behind. 'Here are my friends and here are my roots' as one says (Adriana-Luise Kück, Bremen region, community social volunteer). For multi-localists, it is less the city as the imagined community of an immediate environment that is paramount, but rather the region. Sabine Elbe (22, Leipzig, trainee healing practitioner) describes this as follows: 'Really, I am only whole in Saxony.' The city in which she lives is then a subordinate matter.

Pluralists also make comparisons between cities. All the same, insofar as the city plays a role as an imagined community, it is wrapped into a much more varied horizon of community. What is initially striking is the refusal of any imagined fixed geographical or cultural community. Torsten Breisler (21, Leipzig, student), for example, insists that he feels 'basically $[\ldots]$ neither Bavarian, nor as someone from Munich, but just as little [...] German'. Or Claas Kuhnert (29, Bremen, trainee health service manager) says with respect to Bremen that it is the 'centre of his life'. But on the other hand, 'this could really have been any other city'. Apparently in contrast to this, Claas sees the need for the solidarity of local communities. From this arises his interest in engaging with the city in which he lives, especially when it involves the 'development of a district' or 'culture'. Presumably this was the reason for his temporary involvement with the Bremen Left Party, which ended after disagreements in the local party organization.

If we consider these examples of localists, centrists, multilocalists and pluralists, it becomes clear how specific yet precarious the connection to the city as an imagined community can be. All of those we interviewed ranked their group of friends very much above the city.

\subsection{Conclusion: Community-Building in the Mediatized City}

How can we bring together the different levels of urban communitization that we have discussed in this chapter? We began with a discussion about the role of media in supporting life in the city. On the whole, it is striking how few of what are said to be the current hot topics regarding media-related changes in the city are reflected in the everyday life of the 
young people we interviewed: ideas of a smart city are far removed from their existence, locative media are something that they use tentatively but whose potential for community construction plays little part, while hyperlocal journalism, as with local journalism, had very little resonance among our interviewees, especially the localists among them.

By contrast, our figurational and analytical perspective on the issue of living in the mediatized city highlights the fact that, beyond the family, it is friends who are important in their experience of community in the city: this experience is undertaken with groups of friends for whom, above all, the city represents a space of possibility. The experience of community is, however, segregated by the way that the figurative quality of the community spaces in the city are very different, and that these places are unevenly distributed across the city. The manner in which one group of friends experiences this quite possibly therefore has little to do with how another one does. In addition to this, the idea of the city as an imagined community had relevance for only some of our interviewees, and what this meant for them tended to vary quite widely. Likewise, local political engagement is more the exception than the rule. All the same, a sense of belonging to the city as an imagined community was related to the use of local media content, or communication about this.

These results echo the argument of Robert E. Park that the city is a 'mosaic of little worlds'. Taking account of this, some points can be raised. For one thing, this mosaic is not experienced by young people negatively, but rather as a space of opportunity through which they move with their friends. Park's reflections are today limited by the way that today's media environment promotes media ensembles that tend to stabilize groups of friends rather than foster a divided city public domain. 'Social control'-if one wishes to use this term-takes place primarily within groups of friends as 'interveillance' (Christensen and Jansson 2014: 8 ); there is a degree of pressure to use the favoured media ensemble, so this is not a form of pressure that originates in a public domain. For many, the city remains a-valued-space of opportunity with diverse locations for community construction that are important to them. Only exceptionally is it experienced as a political space of a particular community.

The deep mediatization of the city thus leaves an ambivalent impression. Ideas about the broad possibilities of digital media for urban living are confronted with a young person's reality, in which such speculations are limited to alternative mediatized spaces such as the Hackerspace dealt 
with above, or are important for individuals such as the pluralist Claas Kuhnert (locally political). The mediatized city remains segregated, and only reveals itself as a communal structure once one considers the variety of its diverse communicative figurations.

\section{Notes}

1. Cindy Roitsch and Matthias Berg collaborated on this project and collected the material that underpins this chapter. See for an outline of the results of this project especially Hepp et al. (2014a, b).

2. The following took part in the research seminar: Felix Andrae, Paul Baumgarten, Ulrike Gerhard, Freya Grundmann, Alexander Keßel, Lei Lu, Lisa Pautsch, Kassandra Puderbach, Milena Schulte, Pawadee Tiphyarug and Jana Wagner. They put together the Open Street Map presented in Sect. 5 below, to which we refer in the analysis conducted in that section (see on this Andrae et al. 2015; Baumgarten et al. 2015; Gerhard et al. 2015).

3 . We are referring here to different horizons of communitization and distinguish between localists, centralists, multilocalists and pluralists. See on this Hepp et al. (2014a) as well as our discussion in Sect. 6.

4. All the names here are pseudonyms.

5. On the history of the communal cinema and its governing body see http://www.city46.de. Accessed: 30 March 2017.

6. See http://www.hackerspace-bremen.de. Accessed: 30 March 2017.

7. This coincides with Myria Georgiou's work on a London shopping mall, where she came to similar conclusions—see Georgiou (2013: 51-58).

\section{REFERENCES}

Anderson, Benedict. 1983. Imagined communities: Reflections on the origins and spread of nationalism. New York: Verso.

Andrae, Felix, Freya Grundmann, and Pawadee Tiphyarug. 2015. Mediengebrauch bei situativen Eventvergemeinschaftungen. ZeMKI, MA research report.

Baumgarten, Paul, Alexander Keßel, Milena Schulte, and Jana Wagner. 2015. Alternative Vergemeinschaftungsorte in Bremen. ZeMKI, MA research report. Baym, Nancy K. 2015. Personal connections in the digital age, 2nd ed. Cambridge, Malden: Polity.

Berg, Matthias, and Cindy Roitsch. 2015. Lokalität, Heimat, Zuhause und Mobilität. In Handbuch Cultural Studies und Medienanalyse, ed. Andreas Hepp, Friedrich Krotz, Swantje Lingenberg, and Jeffrey Wimmer, 147-155. Wiesbaden: VS. 
Bolin, Göran. 2004. Spaces of television. The structuring of consumers in a Swedish shopping mall. In Media space: Place, scale and culture in a media age, ed. Nick Couldry and Anna McCarthy, 126-144. London: Routledge.

Bridge, Gary. 2009. Reason in the city? Communicative action, media and urban politics. International Journal of Urban and Regional Research 33 (1): 237-240.

Castells, Manuel. 2000. The rise of the network society. The information age: Economy, society and culture, vol. 1, 2nd ed. Oxford: Blackwell.

Christensen, Miyase, and André Jansson. 2014. Complicit surveillance, interveillance, and the question of cosmopolitanism: Toward a phenomenological understanding of mediatization. New Media \& Society 17 (9): 1473-1491.

Christensen, Miyase, and André Jansson. 2015. Cosmopolitanism and the media. Cartographies of change. London: Palgrave Macmillan.

Christmann, Gabriela B. 2013. Raumpioniere in Stadtquartieren und die kommunikative (Re-)Konstruktion von Räumen. In Kommunikativer Konstruktivismus, ed. Reiner Keller, Jo Reichertz, and Hubert Knoblauch, 153-184. Wiesbaden: Springer.

Christmann, Gabriela B. 2016. Zur kommunikativen Konstruktion von Räumen: Theoretische Konzepte und empirische Analysen. Wiesbaden: VS.

Couldry, Nick, and Andreas Hepp. 2017. The mediated construction of reality. Cambridge: Polity Press.

Elias, Norbert, and John Lloyd Scotson. 1994 [1965]. The established and the outsiders: A sociological enquiry into community problems. London: Sage.

Evans, Leighton. 2015. Locative social media: Place in the digital age. London: Palgrave Macmillan.

Farías, Ignacio. 2010. Introduction: Decentring the object of urban studies. In Urban assemblages. How actor-network theory changes urban studies, ed. Ignacio Farías and Thomas Bender, 1-24. London, New York: Routledge.

Freie Hansestadt Bremen. 2010. Stadtteilbericht Gröpelingen.

Georgiou, Myria. 2013. Media and the city: Cosmopolitanism and difference. Cambridge: Polity.

Gerhard, Ulrike, Lei Lu, Lisa Pautsch, and Kassandra Puderbach. 2015. MedienStadt-Vergemeinschaftung. Eine Untersuchung zur Mediatisierung urbanen Gemeinschaftslebens an Kultur-, Bildungs-und Freizeit-Orten in Bremen. ZeMKI, MA research report.

Glaser, Barney G., and Anselm L. Strauss. 1998. Grounded Theory strategien qualitativer forschung. Bern: Huber.

Hasebrink, Uwe, and Jan-Hinrik Schmidt. 2013. Informationsrepertoires und Medienvielfalt in der Großstadtöffentlichkeit. Eine Untersuchung der Berliner Bevölkerung. In MediaPolis-Kommunikation zwischen Boulevard und Parlament: Strukturen, Entwicklungen und Probleme von politischer und zivilgesellschaftlicher Öffentlichkeit, ed. Barbara Pfetsch, Janine Greyer, and Joachim Trebbe, 161-184. Konstanz: UVK. 
Hepp, Andreas. 2013. Cultures of mediatization. Cambridge: Polity Press. Hepp, Andreas. 2015. Transcultural communication. Malden: Wiley Blackwell. Hepp, Andreas, Matthias Berg, and Cindy Roitsch. 2014a. Mediatisierte Welten der Vergemeinschaftung: Kommunikative Vernetzung und das Gemeinschaftsleben junger Menschen. Wiesbaden: VS.

Hepp, Andreas, Matthias Berg, and Cindy Roitsch. 2014b. Mediatized worlds of communitization: Young people as localists, centrists, multi-localists and pluralists. In Mediatized worlds: Culture and society in a media age, ed. Andreas Hepp, and Friedrich Krotz, 174-203. London: Palgrave.

Hepp, Andreas, Cindy Roitsch, and Matthias Berg. 2016. Investigating communication networks contextually. Qualitative network analysis as cross-media research. MedieKultur 32 (60): 87-106.

Jarren, Otfried. 2013. MediaPolis oder Monopoly? Stadt und Medien als Gemeinschaftsversprechen. In MediaPolis-Kommunikation zwischen Boulevard und Parlament: Strukturen, Entwicklungen und Probleme von politischer und zivilgesellschaftlicher Öffentlichkeit, ed. Barbara Pfetsch, Janine Greyer, and Joachim Trebbe, 51-62. Konstanz: UVK.

Keppler, Angela. 2014. Reichweiten alltäglicher Gespräche. Über den kommunikativen Gebrauch alter und neuer Medien. In Unser Alltag ist voll von Gesellschaft, eds. Alfred Bellebaum and Robert Hettlage, 85-104. Wiesbaden: VS.

Kitchin, Rob, and Martin Dodge. 2011. Code/space: Software and everyday life. Cambridge, MA: MIT Press.

Krajina, Zlatan. 2014. Negotiating the mediated city. Routledge: Everyday encounters with public screens. London.

Lane, Jeffrey. 2016. The digital street: An ethnographic study of networked street life in Harlem. American Behavioral Scientist 60 (1): 43-58.

Massey, Doreen. 1994. Space, place and gender. Cambridge: Polity Press.

Metag, Julia, and André Donk. 2013. Fragmentierung städtischer Öffentlichkeit. Integration soziogeografischer und kommunikationswissenschaftlicher Ansätze. In MediaPolis-Kommunikation zwischen Boulevard und Parlament: Strukturen, Entwicklungen und Probleme von politischer und zivilgesellschaftlicher Öffentlichkeit, eds. Barbara Pfetsch, Janine Greyer, and Joachim Trebbe, 63-82. Konstanz: UVK.

Neal, Zachary P. 2013. The connected city. How networks are shaping the modern metropolis. London, New York: Routledge.

Nielsen, Rasmus K. 2015. Local Journalism-The decline of newspapers and the rise of digital media. London, New York: Tauris.

Park, Robert E. 1967. The city: Suggestions for the investigation of human behaviour in the urban environment. In The city, ed. Robert E. Park, Ernest W. Burgess, and Roderick McKenzie, 1-46. Chicago: University of Chicago Press. 
Rainie, Harrison, and Barry Wellman. 2012. Networked: The new social operating system. Cambridge, MA: MIT Press.

Rauterberg, Hanno. 2013. Wir sind die Stadt!: Urbanes Leben in der Digitalmoderne. Berlin: Suhrkamp.

Simmel, Georg. 2006 [1903]. Die Großstädte und das Geistesleben. Frankfurt am Main: Suhrkamp.

Smith, Neil, and Peter Williams. 2010. Gentrification of the city. London: Routledge.

Strauss, Anselm, and Juliet Corbin. 1996. Grounded Theory: Grundlagen qualitativer Sozialforschung. Weinheim: Beltz.

Strübing, Jörg. 2008. Grounded Theory. Zur sozialtheoretischen und epistemologischen Fundierung des Verfahrens der empirisch begründeten Theoriebildung, 2nd ed. Wiesbaden: VS Verlag.

Townsend, Anthony M. 2013. Smart cities: Big data, civic hackers, and the quest for a new utopia. New York: WW Norton \& Company.

United Nations. 2015. World urbanization prospects. The 2014 revision. New York: United Nations.

Zukin, Sharon, Philip Kasinitz, and Xiangming Chen. 2016. Global cities, local streets. Everyday diversity from New York to Shanghai. New York, London: Routledge.

Open Access This chapter is licensed under the terms of the Creative Commons Attribution 4.0 International License (http://creativecommons.org/licenses/ by $/ 4.0 /$ ), which permits use, sharing, adaptation, distribution and reproduction in any medium or format, as long as you give appropriate credit to the original author(s) and the source, provide a link to the Creative Commons license and indicate if changes were made.

The images or other third party material in this chapter are included in the chapter's Creative Commons license, unless indicated otherwise in a credit line to the material. If material is not included in the chapter's Creative Commons license and your intended use is not permitted by statutory regulation or exceeds the permitted use, you will need to obtain permission directly from the copyright holder.

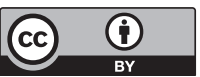

